\title{
Lukasz Makowski
}

Wyższa Szkoła Bankowa w Poznaniu,Wydział Zamiejscowy w Chorzowie e-mail: lukasz.makowski@chorzow.wsb.pl

\section{SYSTEM DEMOKRATYCZNY W RELACJI DO EKONOMII I ZARZĄDZANIA GOSPODARKĄ}

\section{DEMOCRATIC SYSTEM IN RELATION TO ECONOMICS AND ECONOMIC GOVERNANCE}

DOI: $10.15611 /$ pn.2018.529.15

JEL Classification: P1, P10, P16

Streszczenie: Celem opracowania jest wskazanie na konieczność teoretycznego ujęcia demokracji, zawierającej dwa poziomy wyrażania wolności człowieka - poziom jednostkowy i wspólnotowy. Teoria demokracji ma istotne znaczenie dla kształtowania relacji społeczno-ekonomicznych. Obecnie relacje ekonomiczne są dominujące w określaniu kształtu demokracji. Za ich siłą stoją założenia gospodarki neoliberalnej. W kontekście takiego podejścia obserwowane są urynkowione aspekty stosowanej demokracji, wywołujące głębokie zniekształcenia w praktycznych procedurach demokracji. Tematyka została opracowana w trzech punktach prezentujących kolejno: krytykę demokracji posadowionej w systemie gospodarki neoliberalnej, problematykę społeczeństwa obywatelskiego (SO) i kierunki doskonalenia demokracji zapewniającej funkcjonowanie tego społeczeństwa.

Slowa kluczowe: demokracja bezpośrednia/demokracja pośrednia, społeczeństwo obywatelskie, teoria demokracji, zarządzanie gospodarką, polityka ekonomiczna.

Summary: The aim of this study is to indicate the need for a theoretical approach to democracy containing two levels of human freedom: the individual and community level. The theory of democracy is essential for shaping socio-economic relations. Nowadays, economic relations are dominant in defining the shape of democracy. Their strength is supported by the assumptions of the neoliberal economy. In the context of such an approach, the market-oriented aspects of the applied democracy are observed, causing profound distortions in practical procedures of democracy. Definitely a democratic theory is necessary, expressing the synthesis of the freedom of the human individual at the level of their individual will and their freedom in the social field. Society cannot be treated as a human group, but as a unified whole with socialized relations.

Keywords: direct democracy/representative democracy, civil society, theory of democracy, economic governance, economic policy. 


\section{Wstęp}

W praktyce procedury demokratyczne są najczęściej powiązane z danym systemem społeczno-ekonomicznym. Są wtórne wobec systemu. Obecnie system demokracji przedstawicielskiej obsługuje typ gospodarki neoliberalnej, gdzie teza o wolności indywidualnej odgrywa kluczową rolę. Wolność człowieka sprowadza się najczęściej do aktów wyborczych, poprzez które wybierani są przedstawiciele wyborców do parlamentu. To rodzaj demokracji przedstawicielskiej. Formułowane w literaturze przedmiotowej pojęcia demokracji są najczęściej wyprowadzane z obserwacji empirycznych, a w krytycznych dyskursach opisywane są wady i zalety praktycznych form demokracji. To zubożone postępowanie naukowe. Potrzebne są ustalenia na drodze zabiegów teoretycznych. Jak każda dziedzina wiedzy, demokracja wymaga także własnej teorii. Przyjmując, że teoria naukowa jest pewną strukturą dla obserwacji i faktów i że jej zadaniem jest ustalenie zasad prowadzących do dobra ludzkiego, można ustalić kierunek myślowy dla poszukiwania zrębów teorii demokracji. Niezbędny dla demokracji imperatyw wolnościowy i równościowy można ustrukturyzować na dwóch poziomach: wolności człowieka na poziomie jego woli jednostkowej i wolności człowieka na poziomie wspólnoty społecznej, jaką jest społeczeństwo. Człowiek realizuje siebie zawsze we wspólnotach, z może pojedynczymi wyjątkami, niemożliwe jest więc, by jego wolność osobista rozpatrywana była poza tymi wspólnotami. Nie są to dwie sprzeczne wolności, ale wolności tego samego człowieka wyrażone na dwóch poziomach egzystencji: jednostkowej i wspólnotowej. Tego rodzaju teoretyczne uogólnienie jest szczególnie ważne w kontekście rozpatrywania relacji demokracji do ekonomii. Wynika z niego, że ustalone poprzez formy demokracji (demokracji bezpośredniej) normatywy społeczne są konieczne do realizacji wolności w sferze wspólnotowej i mają pierwotne znaczenie dla budowy systemu społeczno-ekonomicznego. Wypracowanie praktycznych procedur demokratycznych ma charakter wtórny, zabezpieczający istnienie tego systemu. Poziom wspólnotowy, w przypadku ekonomii poziom makroekonomiczny, to upodmiotowienie społeczeństwa demokratycznego, wymagające formy SO. Ten ogólny zarys myślowy rozpatrywany jest w opracowaniu w trzech punktach wyjaśniających: zależność obecnego systemu demokracji od neoliberalnego spojrzenia na funkcjonowanie systemu społeczno-ekonomicznego, istotę SO i kierunki doskonalenia systemu demokratycznego.

\section{Demokracja w uwikłaniu neoliberalizmu ekonomicznego}

W sposób powszechnie zrozumiały demokrację od zawsze wiązało się z wolnością człowieka. Wystarczy więc stworzyć taki system demokratyczny, by człowiek mógł realizować wolność osobistą, zapewniał podstawę równości obywateli oraz równości ich szans i możliwości. Z tego punktu widzenia pojęcia demokracji wyrażają na ogół pewne aspekty praktycznych form realizacji demokracji, poprzez które czło- 
wiek może wyrażać swoje preferencje. Zakłada się przy tym, że człowiek potrafi dokonywać właściwych, racjonalnych wyborów. Kategoria racjonalności jawi się jako subiektywna, powiązana jest bowiem z różnymi wartościami, które ceni człowiek i które ujawnia w swych preferencjach. Mamy tu do czynienia z relatywizmem, który dotyczy także kluczowej dla człowieka kategorii etyki. Ma ona charakter względny i nie musi wyrażać zuniwersalizowanego wymogu człowieczeństwa w człowieku. Panujący relatywizm tak mocno koncentruje się na wrodzonych normach wywodzących się z pojęcia „siebie”, z indywidualizacji człowieka, że pojęcie odpowiedzialności etycznej się rozmywa [Stankiewicz 2010, s. 12].

Współcześnie rozpowszechniona jest $\mathrm{w}$ świecie doktryna neoliberalizmu wyznaczająca koncepcję ustroju społeczno-ekonomicznego w większości krajów świata. Empiryczne obserwacje stanowią podstawę do uogólnień pojęcia demokracji, z tego też powodu uznano, że najlepszą formą tak rozumianej demokracji jest demokracja przedstawicielska. Realizacja idei wolności w systemie parlamentaryzmu zawiera swoje słabości, zasada większości bowiem nie może wyrazić jednolitego stanowiska wobec sprzeczności interesów różnych grup. Zasada większości nie wyraża jakiegoś poziomu interakcji różnych interesów obywateli. $Z$ drugiej strony jest to pośredni sposób kształtowania woli państwa, a więc wolę tę tworzy nie bezpośrednio naród, lecz wybrany przezeń parlament [Stankiewicz 2010, s. 42].

Idea demokracji parlamentarnej jest mocno krytykowana. H. Kelsen zauważa, że wśród argumentów przytaczanych przeciw parlamentaryzmowi najistotniejszy jest ten, iż ukształtowana przez parlament wola państwa nie jest wcale wolą narodu, w rezultacie czego jednostki stają się bierne i nie wierzą we własne siły [Ziżek 2014, s. 15]. F. Hayek w Konstytucji wolności uznał wolność, zgodnie z doktryną liberalizmu, za najważniejsze prawo społeczne [Kowalczyk 1999, s. 228]. Jednak to pojmowanie wolności jest mocno eksponowane w indywidualistycznym liberalizmie ze względu na możliwości systemowego wyrażenia tej koncepcji w normach prawnych. Uważa się, że demokracja musi unikać ekstremów: z jednej strony anarchizacji, z drugiej zaś autorytaryzmu państwowego. Niewątpliwie przestrogi te są bardzo ważne, jednak istoty demokracji nie wyjaśniają, co zresztą uwidacznia się we współczesnych odmianach różnych liberalizmów. Program neoliberalny prowadzi do tego, że demokracja w pełnym znaczeniu w sferze politycznej ma ograniczone możliwości oddziaływania na sprawy gospodarcze. Z istoty swej demokracja winna zmierzać do równości, gdy tymczasem liberalizm prowadzi do rozwarstwienia dochodowego. Być może jest demokracja w sensie powszechnych, ale praw nie odnosi się to już do kluczowych aspektów materialnej i duchowej strony ludzkiego życia. Neoliberalizm wierzy w uzdrawiającą, zarazem efektywnościową siłę gospodarki rynkowej. Powierzenie kontroli rynku nad systemem gospodarczym, w tym także systemem demokracji, ma przemożne konsekwencje dla całej organizacji społeczeństwa i w gruncie rzeczy oznacza traktowanie społeczeństwa jako „przybudówki” rynku. Tworzy się ,społeczeństwo rynkowe”. 
Niewątpliwie idea demokracji nie może wyrazić różnorodności interesów grup społecznych i z konieczności musi się ona posiłkować kategorią większości. Z drugiej strony prawdziwe jest stwierdzenie, „że liczba osób wyrażających jakiś pogląd nie czyni go tym samym godnym szerzenia i naśladowania" [Szyszkowska 2012, s. 9]. Nie oznacza to, że zarysowany tu problem nie może zostać rozwiązany. Możemy ustalić uniwersalne wartości, wokół których może być organizowana większość wartości „spinających” społeczeństwo w pewną całość. Zatem pierwotnym zadaniem społeczeństwa jako całości jest ustalenie wartości kierunkowych wyrażających długookresowe cele, niezbędne do rozwoju społeczeństwa jako całości, a następnie poszukiwanie takich form demokracji, w których możliwa byłaby realizacja tych celów. Problem nie leży więc w próbach rozwikłania sprzeczności wyłaniających się z różnych poglądów, ale w ponownej refleksji nad treścią samej demokracji, dla której szczególnie ważny jest zestaw wartości możliwych do zaakceptowania przez wszystkich członków społeczeństwa. Pojawia się tu niezwykle ważny teoretycznie problem ustalenia właściwych treści demokracji i form jej stosowania. Wymogiem teorii każdej wiedzy, w tym także demokracji jako teorii politycznej, jest ustalenie pewnych zasad wspólnych, sprzyjających dobru człowieka, jego rozwojowi. Z tego punktu widzenia demokracja nie może oznaczać jedynie zestawu określonych procedur i nie wolno jej opierać na relatywistycznym zestawie wartości, ale wartości mających uniwersalny charakter, które społeczeństwo może uznać za wartości normatywne. Taki pogląd wyznaje W.J. Stankiewicz w swoich argumentach przeciwko modnemu dzisiaj behawioralizmowi, odrzucającemu wartościowanie i normatywizm oparty na wartościach. Wartości uniwersalne to przede wszystkim normy etyczne, odwołujące się do prawa naturalnego człowieka, prawa dotyczącego dobra człowieka i wyrażającego jego człowieczeństwo. Należy zauważyć, że jeśli nie ma obiektywnego zdefiniowania norm etycznych, to mogą one być narzucane przez różne siły i wtłaczane w świadomość społeczeństwa. Obywatele mogą dokonywać wyborów pod naciskiem standardów narzuconych przez pewne grupy społeczne, mające określony interes. Jak twierdzi W.J. Stankiewicz, system głosowania, który nie bierze pod uwagę żadnych normatywnych założeń, nie odzwierciedla istoty demokracji. Stary problem praw i prawa naturalnego, wolności i równości oraz podobne kwestie są tu ignorowane [Stankiewicz 2010, s. 13]. Nie można demokracji sprowadzać do wymiaru proceduralnego. Jeśli człowiek ma dokonywać w systemie demokratycznym wyborów, decydować w ten sposób o społeczno-ekonomicznych przemianach systemowych, to powinien mieć właściwą orientację intelektualną, społeczną, orientację co do wartości, poprzez które chce manifestować swoje preferencje.

Stwierdzenie, że w centrum przemian stoi człowiek wraz z pożądanymi przez niego preferencjami wartości, określającymi jego egzystencjalną bytowość, nie budzi kontrowersji, gdy pozostajemy na bardzo ogólnym poziomie ich artykułowania. Gdy cele łączymy z jednostką ludzką, gdy następuje proces ich uszczegółowiania, to rzecz jasna wchodzimy w obszar relatywizmu i nie można go lekceważyć, je- 
śli mamy mówić o wolności człowieka jako indywiduum. Człowiek jako jednostka bogato uformowana, jednostka mająca prawo do indywidualnego rozwoju, powinien mieć możliwość realizowania swoich preferencji w systemie demokratycznym. Tyle że jednostkowe preferencje nie znoszą normatywności ogólnych idei dobra człowieka, jego wartości etycznych, tak ściśle związanych z prawem naturalnym człowieka. Normatywne idee ukierunkowujące przemiany w systemie społeczno-ekonomicznym czy kulturowym nie stoją bynajmniej w sprzeczności z jednostkowym interesem człowieka. System demokratyczny powinien posiadać rozwiązania zapewniające przekształcenia woli człowieka w wolę powszechną. Innymi słowy, racjonalizm jednostkowy człowieka nie może być barierą dla filozofii społecznej, dla etyki ludzkości jako bytu całościowego. Jest rzeczą oczywistą, że racjonalizm jednostkowy człowieka nie może być lekceważony w demokracji, winna ona zapewnić warunki do jego spełnienia, jednak po zabezpieczeniu tych celów, które są użyteczne dla wszystkich i które bynajmniej nie pozostają w sprzeczności z racjonalnością jednostkową. Chodzi tu o możliwość wyartykułowania w demokracji celów wspólnych dla wszystkich, a więc także dla jednostki, celów, które jednostka nie jest w stanie realizować w trybie indywidualnego wyboru. Może je realizować na poziomie wspólnotowym. Potrzebna jest więc teoria demokracji, na którą wskazuje W.J. Stankiewicz, która potwierdza dwa poziomy artykułowania celów jednostkowych człowieka, albo innymi słowy, dwa poziomy jego własnej racjonalności, możliwe do spełnienia we właściwej konstrukcji demokracji.

W obecnie przyjętym systemie demokracji parlamentarnej zakłada się, że zadaniem demokracji jest zapewnienie wolności człowieka do realizacji jego osobistych celów, a ponieważ te cele są subiektywne, są relatywne, to muszą być podporządkowane większości.

O celowości wartości, które może realizować jednostka w systemie tak rozumianej demokracji, decyduje większość. Rozumna jest większość, więc normy prawne mają odzwierciedlać osąd większości, której winna się podporządkować jednostka. Nie byłoby w tym nic dziwnego, gdybyśmy normy większości uznali za obiektywne, racjonalność większości za obiektywną, przesądzającą o istotowości człowieka jako jednostki indywidualnej. Tak jednak nie jest, albowiem normy większości mają także charakter relatywny. Nieracjonalna może być jednostka, nieracjonalna może być większość. Koncepcja racjonalności, tak w aspekcie jednostkowym, jak i społecznym, wymaga odwoławczego kryterium w postaci uniwersalnych wartości sprzyjających rozwojowi człowieka, zarówno w sferze materialnej, jak i duchowej.

Definiując pojęcie demokracji, oprócz innych atrybutów, wymienia się ,ustrój społeczno-gospodarczy zapewniający powszechny równy udział obywateli we własności i zarządzaniu narodowym majątkiem produkcyjnym, dostęp do dóbr kultury, oświaty i ochrony zdrowia; jest to tzw. demokracja społeczna i ekonomiczna" [Nowa Encyklopedia... 1995, s. 55]. Tak rozumiana demokracja wiąże to pojęcie zarówno z możliwością realizacji wolności obywatelskiej, jak i upodmiotowieniem społeczeństwa, które może decydować o kształcie własnej bytowości materialno-ducho- 
wej. Zatem pojęcie demokracji jawi się jako warunek spełniania wolności jednostkowej człowieka, ale także jego wolności w wymiarze społecznym. Tak rozumiana demokracja nie określa jeszcze jej istoty, konieczne jest tu pierwotne określenie treści pojęcia upodmiotowienia, przekonanie o celowości, na którą nakierowana byłaby wolność osobista człowieka. Rozumną celowością może być tylko obiektywne kryterium wartości, rozstrzygające się w obszarze natury człowieka i jego ideałów kształtujących celowość jego ścieżki życia. „Odbrązawiające spojrzenie na ludzką naturę może doprowadzić do sensowych przemian w życiu publicznym i jednostkowym" [Szyszkowska 2012, s. 39]. Chodzi tu o wartości, które w ciągłości życiowej człowieka nie tylko umożliwiają mu poprawę materialnego statusu egzystencji, ale sprzyjają rozwojowi jego osobowości, jego człowieczeństwa. „Błędem jest bowiem troska o rozwój intelektualny i jednoczesne pozostawianie na uboczu rozwoju duchowego człowieka, jak również kształtowania siły charakteru" [Szyszkowska 2012, s. 39]. Zatem w pomyśle na demokrację należałoby uwzględnić realizację ustroju społecznego o określonej aksjologii, broniącej godności samego człowieka [Szymonik 2010, s. 199], sprzyjającego jego rozwojowi. Historycznie obserwowane doświadczenia wskazują, że w proponowanych rozwiązaniach demokratycznych imperatyw wolności nie został dookreślony. Sądzić należy, że człowiekowi nie chodzi o zupełną wolność, ale o wolność od czegoś niegodnego, niepożądanego, czegoś, co określa niechcianą przez niego treść jego życia. Wolność potrzebna jest człowiekowi, gdy ma sformułowane cele własnego życia i potrzebuje warunków do ich realizacji. Sformułowanie tych celów jest efektem wyboru pewnych wartości. Zatem teoretyczna refleksja nad właściwymi formami demokracji wymaga poprzedzająco ustalenia wartości, którym ma sprzyjać dany model demokracji. $Z$ tego punktu widzenia model demokracji, tak powszechnie propagowany w liberalizmie, zawiera wewnętrzną sprzeczność. Głoszone przez liberalizm hasła wolności są celem samym w sobie, podczas gdy wolność to tylko warunek konieczny do realizowania pożądanych przez człowieka celów. „Gdy nie ma jasno określonych celów, to przedstawiciele władzy mają możliwość realizowania własnych, uświadomionych przez nich celów, a więc celów relatywnych lub po prostu celów różnych grup społecznych. Nieprzypadkowo pojawiło się słowo lobbing polityczny niewywołujące sprzeciwu politycznego. A jak widzimy w dobie globalizacji nazbyt często wolę przedstawicieli władzy kształtują postulaty korporacji, a nie społeczeństwa" [Patel 2010 s. 147]. Najczęściej są to postulaty dotyczące stworzenia struktury rynku wygodnej dla interesów wielkich korporacji lub ludzi o silnej pozycji majątkowej. Społeczeństwo powinno mieć możliwość sprawdzenia granic rynku. Granic tych nie ustalą w systemie prawnym prawnicy ani urzędnicy. Społeczną płaszczyznę rozumienia założeń ustrojowych ludzie mogą uzyskać tylko poprzez szczerą i otwartą debatę społeczną. Inaczej obserwujemy pewien cyrkowy obraz iluzji wolności obywatelskiej.

To w umowie społecznej zawarta jest teoretyczna treść demokracji, określająca jej kierunkowy charakter, w niej tkwi najistotniejsza cecha demokracji, zapewniająca zgodność ze sferą wartości zarówno indywidualizmu, jak i społeczeństwa jako 
całości. Dopiero tak rozumiana umowa społeczna może wyznaczać kształt ładu społeczno-ekonomicznego, porządkującego życie społeczeństwa w różnych warstwach jego bytowania. To w umowie społecznej muszą być wyrażone uświadomione pierwotne cele społeczeństwa demokratycznego, wywodzące się ze zrozumienia natury człowieka i jego sensu życia, a więc cele wyłaniające się ze zrozumienia prawa naturalnego, jego znaczenia dla określenia ładu społecznego, tak istotnego dla projekcji sensu życia każdego człowieka. Nie można zatem ubolewać, że obecny system demokracji nie rozwiązał jeszcze problemu konfliktu między członkami społeczeństwa a ładem społecznym. Problemem demokracji nie jest rozwiązywanie tego konfliktu, a stworzenie płaszczyzny do wyłonienia wartości uznających zarówno indywidualizm, jak i cele wspólnotowe. Możliwość realizacji tych wartości ma zapewnić stworzony ład społeczno-ekonomiczny. Tylko taki ład spowoduje, że rząd i społeczeństwo będą istnieć dla dobra jednostki. Teoria demokracji dla stworzenia swoich zasad winna posiłkować się wiedzą interdyscyplinarną. Musi ona przeciwstawić się relatywizmowi, to jest temu, co zaciemnia rozsądne założenie o naturze człowieka. „Podstawą postępowej polityki może być jedno, co nas łączy jako gatunek - nasze człowieczeństwo" [Patel 2010, s. 147]. J. Dewey słusznie sądził, że nie ma opozycji pomiędzy wolnością wewnętrzną jednostki a regułami życia społecznego. Nie istnieje wolność jednostek czy grup ujmowanych abstrakcyjnie, tj. w oderwaniu od życia społecznego. Wolność człowieka jest relatywna i relacyjna [Kowalczyk 2005, s. 164]. Ona realizuje się zawsze w konkretnych społecznych relacjach, strukturach i uwarunkowaniach. Wynika z tego, że wolność człowieka nie jest wyizolowanym stanem odczuwania, zależy w dużej mierze od jego uwarunkowań ekonomicznych. Relacja ekonomii do demokracji winna być jednak wtórna, wobec pierwszeństwa demokracji tworzącej warunki do artykułowania celów społecznych. Społeczeństwo ma prawo do określania własnego systemu społeczno-ekonomicznego.

\section{Model społeczeństwa obywatelskiego - konsekwencją istotowego zrozumienia demokracji}

Już w starożytnej Grecji zwrócono uwagę, że demokracja ma zastąpić rządy niewielu rządami obywateli. W dalszym ciągu głównym problemem kształtowania systemów demokratycznych pozostaje rozstrzygnięcie stosunku jednostki do społeczeństwa. Należy mocno zaakcentować, że rozpatrywane tu zagadnienie stosunku jednostki do społeczeństwa ma kluczowe znaczenie dla kształtowania systemów demokratycznych. Każdy system można oceniać przez pryzmat tego stosunku, pod warunkiem że mamy niezbędną jasność w tej kwestii, upoważniającą do oceny kształtu danej demokracji. Zagadnienie jest teoretycznie złożone, abstrakcyjnie nieuświadomione prowadzi do mnogości pojęć demokracji budowanych na poziomie empirycznego postrzegania. W istocie różnorodność definicji demokracji wynika z szerokiego zakresu zagadnień, które najczęściej obserwowalne są w życiu praktycznym. Według Ch. Tilliego istnieją pojęcia demokracji konstytucyjnej, rzeczowej, proceduralnej 
i procesowej [Śliwa 2010, s. 18]. Nie rozpatrując w tym miejscu szczegółowo tych pojęć, stwierdzić należy, że dla demokracji rozpatrywanej z punktu widzenia systemu społeczno-ekonomicznego najbardziej przydatne jest podejście rzeczowe. To podejście do demokracji skupia się na warunkach życia i polityki, jakie umacnia dany system. Wymaga odpowiedzi, czy system społeczno-ekonomiczny umacnia dobrobyt ludzi, wolność jednostki, bezpieczeństwo, sprawiedliwość, równość społeczną, a przede wszystkim czy służy rozwojowi samego człowieka. Rzeczowe podejście do demokracji nieczęsto jest rozpatrywane, ponieważ niezwykle jest trudno osiągnąć kompromisy między tymi zasadami, tak ważnymi z punktu widzenia społecznego. Zakłada się, że kompromisy takie należałoby pierwotnie wbudować najpierw w dany model społeczno-gospodarczego rozwoju społeczeństwa, by potem poprzez demokrację weryfikować ich urzeczywistnienie. Wobec braku takiego kompromisu najczęściej rozpatrywane jest podejście proceduralne do demokracji. Zwolennicy tego podejścia wyodrębniają pewien wąski zespół praktyk rządowych i badają, czy demokracja prowadzi do zmian kadry i polityki rządu, badają zgodność wprowadzanych zmian z obietnicami wyborczymi. W celu udoskonalenia demokracji proponowane są różnego rodzaju referenda, petycje, badania opinii społecznych. Oczywiście, wszystkie te procedury są stosowane post factum i w istocie są mało skuteczne. Zagadnienie w aspekcie teoretycznym jest złożone i jak już wspomniano, jego nieuświadomienie prowadzi do mnogości pojęć demokracji budowanych na poziomie empirycznego postrzegania.

Dla demokracji SO, bo o to chodzi z punktu widzenia istoty demokracji, rzecz nie polega na karkołomnym poszukiwaniu kompromisów, a znalezieniu dwóch poziomów: indywidualnego i wspólnotowego, dla wyrażenia interesu jednostkowego. Chodzi tu nie tylko o wyartykułowanie interesów jednostki w jej perspektywie indywidualnej, ale także jej interesu, tyle że mającego szansę na realizację na poziomie wspólnotowym. Interes jednostki na poziomie wspólnotowym należałoby wcześniej w drodze debaty społecznej ustalić, wyrazić go w formie celowości społeczeństwa gospodarującego i pierwotnie wbudować w dany model społeczno-gospodarczego rozwoju społeczeństwa. Niewątpliwie byłoby to znakomite zaplecze budowy właściwych systemów demokratycznych, w rezultacie systemów społeczno-ekonomicznych, o uformowanej wcześniej strukturze makroekonomii. To ona uosabiałaby treść substancji społecznej wyrażającej wspólną celowość społeczeństwa gospodarującego. W drodze praktycznych form demokracji można już wtórnie weryfikować urzeczywistnianie tej treści. Tu mogą być rozpatrywane podejścia proceduralne do demokracji. Jedno, wyodrębniające pewien wąski zespół praktyk kontrolujących, czy demokracja prowadzi do zmian kadry i polityki rządu, badających zgodność wprowadzanych zmian z obietnicami wyborczymi. Drugie, badające skuteczność procedur poprzez odniesienie do głównego kryterium - celowości ustalonej na poziomie wspólnotowym. Dla ustalania celów wspólnotowych ważna jest jasność dotycząca pojęcia społeczeństwa i roli jednostki w społeczeństwie. N. Elias w The Society of Individuals ujął zasadniczy problem: nie przeciwstawia on jednostki społeczeństwu, 
nie są to dla niego ścierające się siły, ale wzajemnie dopełniające siły „,wzajemnego zapładniania: oto społeczeństwo kształtuje indywidualność swoich członków, a jednostki poprzez swoje działania kształtują społeczeństwo zgodnie z prawdopodobnymi i możliwymi strategiami w obrębie utkanej społecznie sieci wzajemnych zależności" [Bauman 2008, s. 59]. W tym rozumieniu nowoczesne społeczeństwo istnieje poprzez akt indywidualizacji, który może zaistnieć nie tylko na poziomie mikro (jednostkowym), ale i poziomie wspólnotowym (makro). SO jako upodmiotowiony podmiot winno decydować o substancji społecznej celów wspólnotowych, zatem wolność jednostki nie jest pozostawiona do realizacji tylko w płaszczyźnie mikroekonomicznej, może być wyrażana także na poziomie makroekonomii. Te właśnie dwa poziomy wyrażania osobistej woli jednostki i jej woli w bycie społecznym, w którym ona przebywa, winny nadawać treść danego modelu systemu demokracji, systemu wymagającego formy SO.

Poszukiwanie takiego modelu w pierwszym rzędzie musi mieć wymiar teoretyczny uwzględniający holistyczne podejście do demokracji i nie może opierać się na empiryzmie społecznym w wyznaczaniu stosowanych procedur demokratycznych. Obecna praktyka wskazuje, że ,współczesne systemy demokracji przedstawicielskich dążą do maksymalizacji udziału obywateli w podejmowaniu decyzji, które nie mają (bezpośredniego) wpływu na sprawowanie rządów. Rolą ludu jest wybór przywódców, którzy w jego interesie - wedle tego, co uznaje się za jego interes będą (na mocy legitymizacji powszechnej) administrować, to znaczy korzystać ze swoich kompetencji ograniczanych ze względu na hipotetyczne i faktyczne możliwości korupcyjne" [Olbromski 2011, s. 24]. W wyniku stosowania form demokracji przedstawicielskiej często do głosu dochodzą jednostki przeciętne, których interesy górują nad dobrem ludzkości, określają losy świata. Gdyby stosować formę demokracji pośredniej uzupełnianej demokracją bezpośrednią, powstałyby lepsze warunki do zlikwidowania tej ułomności.

W różnych formach gospodarki liberalnej zbyt radykalne przeciwstawianie jednostki i społeczeństwa nie występuje, albowiem społeczeństwo pojmowane jest jako organizacja cywilna. I w takim rozumieniu docenia się tu pogląd o występowaniu podmiotowości społeczeństwa. Nie chodzi tu jednak o podmiotowość zarządzającą procesami gospodarczymi, ale o podmiotowość organizującą te procesy. Koncepcję społeczeństwa cywilnego głębiej wyjaśnił A. Tocqueville w pracy $O$ demokracji w Ameryce [Tocqueville 1976, s. 35]. To jest inna kategoria pojęciowa niż SO. Rozumiał społeczeństwo cywilne jako stowarzyszenia, które mogą tworzyć grupy dla swoich ekonomicznych interesów. I wtedy teza o pierwszeństwie państwa przed społeczeństwem cywilnym jest jasna. W koncepcji SO jego byt ontologiczny jest pierwotny dla pomysłu zorganizowania państwa.

Pojęcie SO jest różnie rozumiane, dla ujęcia jego bytowości ontologicznej wymagana jest teoretyczna obróbka. Jest to kwestia niezwykle ważna, gdyż kategoria SO jest konieczna do naświetlenia wielu problemów społeczno-politycznych i ekonomicznych, a przede wszystkim realizowania właściwej formy demokracji. Z całą 
pewnością koncepcja SO musi obejmować istotę wartości odwołujących się do natury człowieka i tylko w takim sensie może być uzasadnieniem wspólnoty politycznej. Nie rozwinie się współdziałanie społeczne, gdy zabraknie podstawowych, powszechnie akceptowanych wartości inspirowanych poszukiwaniem prawdy i dobra, jako dóbr wspólnych. „Dobro wspólne ma dwojaki wymiar: ontologiczny i aksjologiczny. Jego wymiar ontologiczny jest konsekwencją faktu, że ludzka społeczność to zespół rozumnych i wolnych osób. Dobro wspólne nie może nigdy kolidować z moralnym dobrem ludzkiej osoby. Drugi, aksjologiczny wymiar dobra wspólnego to szeroko rozumiana kultura umysłowo-duchowa człowieka, zwłaszcza zaś kultura moralna. Demokracja nie może więc ignorować wartości etycznych, gdyż bez nich traci swój głębszy sens i trwałość" [Kowalczyk 2005, s. 18-19]. Idee równości i sprawiedliwości społecznej jako powszechnie akceptowane dla SO są niewystarczające do kształtowania relacji ekonomicznych. Idea sprawiedliwości społecznej dostarcza kryteriów oceny właściwego podziału dóbr pomiędzy obywatelami, idea równości oznacza równy dostęp do warunków kształtujących egzystencję człowieka. Sformułowane w ten sposób idee mają charakter statyczny, chodzi jednak o to, by SO miało możliwość ustalania tych wartości, które stanowią potencjalne warunki jego rozwoju. Na każdym etapie jego rozwoju te warunki będą się zmieniać. Demokratyczne formy praktycznej realizacji wolności winny mieć charakter dynamiczny, zarówno w wymiarze jednostkowym, jak i społecznym człowieka, i wymagają ciągłego doskonalenia. Relacje demokracji do ekonomii mają zaś dwukierunkowy charakter. Pierwotną siłą w określaniu tych relacji jest koncepcja demokracji obywatelskiej, jej teoretyczne zasady, wtórnie na poziomie praktycznym procedury demokratyczne mają pozwolić na realizację, ustalonego wcześniej przez społeczeństwo, systemu społeczno-ekonomicznego.

\section{Doskonalenie systemu demokratycznego warunkiem społeczeństwa obywatelskiego}

Dominująca obecnie sfera ekonomiczna nad polityczną i prawną przekreśla w dużej mierze ustalanie wzajemnych zależności społeczno-ekonomicznych poza wpływem ekonomii. Demokracja nie określa tu formy ustroju społeczno-gospodarczego, a jedynie jest formą realizacji takiego ustroju. Jak już wspomnieliśmy, panujący neoliberalizm rozszerzył ideę wolnego rynku na sam system wyborczy, wprowadzając narzędzie kształtowania świadomości politycznej w postaci marketingu politycznego, który stosowany jest skutecznie w trakcie wyborów. Kampanie przedwyborcze polegają na sprzedaży własnego wizerunku, łatwo wpadających w ucho haseł wyborczych, a nie na prezentacji konkretnego programu społeczno-gospodarczego. Dyskurs na poziomie uproszczonych, powszechnie powielanych idei toczy się głównie za pośrednictwem mediów masowych. Dzieje się to między innymi z wykorzystaniem wyników sondaży opinii publicznej, za pomocą których można kreować poparcie społeczne dla określonych partii politycznych. Z nich to wyborcy dowia- 
dują się, kto ma wysokie notowania, a kto znajduje się ,ppod kreską”. Zniekształcona w ten sposób opinia publiczna zastępuje społeczeństwu tę właściwą [Guzik 2012, s. 21-22], nieujawnioną publicznie. Partie oferują swoim wyborcom oferty programowe wyposażone w bardzo ogólne hasła, które nie pozwalają zidentyfikować rzeczywistych celów. Niebezpieczeństwem tak prowadzonych kampanii wyborczych jest konkurencja „w dół”, a nie „w górę”, nie troska o przedstawienie najlepszego programu i najlepszych ludzi, a pokazanie przeciwników w najgorszym świetle [Wilkanowicz 1993, s. 241]. Ułomność demokracji przedstawicielskiej może ograniczyć demokracja wyrażająca ideę SO, dla którego istotne są formy demokracji bezpośredniej - chodzi tu o pokonanie modelu demokracji przedstawicielskiej zawężonego do uczestnictwa obywateli jedynie w akcie wyboru. Zatem demokracja bezpośrednia rozumiana jest jako część uzupełniająca funkcjonującego systemu wybieranego parlamentu i partii politycznych. Zainteresowanie tego rodzaju demokracją bezpośrednią rośnie w wielu krajach UE [Linder 2011, s. 11-12]. Ma być ona antidotum na formę demokracji przedstawicielskiej, która nie zapewnia wyrażania poglądu przez społeczeństwo w trakcie sprawowania władzy politycznej. A przecież wiele poważnych kwestii, które nie mogły pojawić się w programach partii politycznych, na skutek nowych okoliczności może wystąpić i w sposób decydujący wpływać na kształt życia obywateli. Społeczeństwo powinno mieć możliwość wprowadzania „swoich” korekt, w bardzo ważnych społecznie kwestiach, pomiędzy wyborami. Niezależnie od tego musi mieć możliwość kontroli haseł wyborczych. Jedną z form demokracji bezpośredniej są referenda społeczne. Obecnie bezpośrednie formy polityki odpowiedzialności oparte na referendum stają się bardziej możliwe do zrealizowania i pożądane, ponieważ obywatele są lepiej wykształceni i mogą dokonywać rozsądnych wyborów polityki, szczególnie gdy obecny postęp technologiczny ułatwia obywatelom możliwość debaty i podejmowania decyzji [Saward 2008, s. 149]. Bardzo dobrze ten system sprawdza się chociażby w Szwajcarii.

Referendum ma i swoje ujemne strony, zbyt wolno podejmuje się decyzje i czasami jest niezdolne do przeprowadzenia innowacji. Niewątpliwym mankamentem jest to, że referendum jako czynnik wywierający nacisk wzmacnia władzę dobrze zorganizowanych i gotowych do konfliktu grup interesów. Badania wskazują, że partie polityczne potrafią skutecznie stosować instrumenty demokracji bezpośredniej do mobilizacji własnych interesów. Demokracja bezpośrednia jest poniekąd demokracją średnich warstw [Linder 2011, s. 18-20]. Wymienione tu słabości demokracji bezpośredniej powodują, że debata o tego rodzaju demokracji jest w dalszym ciągu kontrowersyjna.

Większość politycznych myślicieli uważa demokrację bezpośrednią za bezcelową, bo przeciętny obywatel potrafi określić co najwyżej właściwości polityków, nie jest w stanie podejmować politycznych decyzji. Pogląd taki z natury ubezwłasnowolnia społeczeństwo i niekoniecznie jest słuszny, zwłaszcza że jest w prostej linii oskarżycielski pod adresem elit. To właśnie, że przeciętny obywatel nie potrafi podejmować decyzji politycznych, wynika z tego, że w uświadomieniu sensu tych 
decyzji nie biorą udziału elity intelektualne. Nie tworzy się, choćby w mediach, szerokiej płaszczyzny do debat różnych przedstawicieli nauk społecznych, filozoficznych, teologicznych i innych. Najprostszym przykładem jest brak debat o alternatywnych koncepcjach ekonomicznych, także w literaturze naukowej mają niewielką szansę na przebicie. Dominuje powszechność i uległość. Z tego punktu widzenia formy demokracji bezpośredniej powinny być udoskonalane, ale nie można ich nie stosować i skazywać społeczeństwo na pozostawanie w matni tych samych od lat sił politycznych, wygrywających wybory za pomocą wyrafinowanych form marketingu politycznego. Z teorii demokracji wynika jednoznacznie, że demokracja bezpośrednia nie powinna być tylko korektą dla demokracji przedstawicielskiej, ale posiadać własne poziomy swego zaangażowania. $\mathrm{W}$ dobie obecnej stoi ona jeszcze przed wyzwaniami płynącymi z zewnątrz. Wraz z globalizacją i liberalizacją rozmywają się granice niegdyś wyłącznie narodowej gospodarki i obniża się kontrola państwa nad cyrkulacją kapitału, usług i informacji. Suwerenność jako wartość najwyższa w kontekście konkretnego kraju nie znajduje pokrycia w rzeczywistości [Vatter 2011, s. 23-25]. Jest to wielkie wyzwanie dla różnych form demokracji bezpośredniej. W demokracji bezpośredniej SO musi mieć możliwość wprowadzania własnych celów społecznych tworzących wizję rozwojową ich własnej egzystencji, w nawiązaniu do prawa naturalnego, prawa o istocie dobra ludzkiego $\mathrm{O}$ tym, że istnieje taka konieczność, świadczą często widoczne różnice między elitami świata polityki a społeczeństwem, kiedy wyniki referendum stoją w sprzeczności z rozwiązaniami przyjętymi przez większość parlamentarną. Wynika z tego, że te dwie demokracje, przedstawicielska i bezpośrednia, powinny istnieć obok siebie. Dopóki jednak montowanie form demokracji przedstawicielskiej i bezpośredniej dokonywać się będzie w obrębie systemu liberalnej gospodarki, dopóty sprzeczności te będą, choć na pewno są mocno złagodzone, podobnie jak formy interwencjonizmu łagodzą radykalizm rozwiązań liberalnych. Do dokonywania właściwych ocen demokracji bezpośredniej, a następnie zaprojektowania właściwych jej form, potrzebna jest najpierw solidna krytyka teoretycznych podstaw demokracji przedstawicielskiej. H. Kelsen jest świadom, że zgodność woli jednostki z państwowym porządkiem, nawet w państwie demokratycznym redukującym zbieżność między jednostką a państwem do minimum - jest postulatem utopijnym [Pieniążek 1988, s. 102]. Tym samym wskazuje on na zakorzenienie pierwotnej podstawowej sprzeczności między państwem a jednostką, a potem wtórne łagodzenie tej sprzeczności na drodze form demokracji bezpośredniej. Naprawę systemu demokracji widzi dwutorowo, tj. w częściowym uwiarygodnieniu idei reprezentacji poprzez próbę reformy parlamentaryzmu, by wpływ narodu nie ograniczał się tylko do aktu wyborów, i rozwijanie instytucji referendum czy instytucji inicjatywy ludowej [Pieniążek 1988, s. 104-105]. Rozwijanie instytucji referendum czy instytucji inicjatywy ludowej powinno pójść w kierunku rozwijania form zapewniających formułowanie celów społecznych i współudział narodu w ustawodawstwie. Dla wdrażania form demokracji bezpośredniej w SO ważna jest świadomość społeczeństwa, w szczególności rozwój postaw obywatelskich. 
W praktycznym wymiarze należy mocny akcent położyć na edukację społeczeństwa. System demokracji obywatelskiej winien zapewnić utożsamianie się działań obywatela z państwem. Dla spełnienia tego wymogu demokracja polityczna musi łączyć się z egalitaryzmem, ze sprawiedliwością społeczną, potrzebą edukacji ogólnej i obywatelskiej społeczeństwa, w tym przede wszystkim jego najniższych warstw społecznych [Ziżek 2014, s. 272-273]. Są to postulaty ogólnych wartości społecznych, które mogą być wprowadzane jedynie w modelu SO, w którym istnieje głębokie poszanowanie dla instytucji demokratycznych oraz pluralistyczna kultura polityczna [Ziżek 2014, s. 88-89]. Rozwój wspólnoty obywatelskiej potrzebuje „sfery publicznej, w której obywatele wypracowują nawyki obserwowania i ograniczania działalności państwa i klasy politycznej oraz wyrażania swoich opinii, jak i organizowania się w grupy mające realizować jakieś cele ogólne" [Broda-Wysocki 2003, s. 16]. Wartości społeczne mogą być realizowane poprzez poszerzenie sfery publicznej, wbudowanej w sam mechanizm ekonomiczny, w którym przebiega reprodukcja życia materialnego i duchowego społeczeństwa. Demokracja ma umożliwiać system polityczny, który swoje uzasadnienie może znajdować w tym, co określamy pojęciem dobra człowieka [Legutko 2010, s. 18].

Demokracja nie może działać na zasadzie indywidualizmu, albowiem nie można określić na tyle szerokiego zakresu praw, by spełniały wymagania indywidualizmu. Czynione korekty poprzez formy demokracji bezpośredniej nie przyniosą oczekiwanych rezultatów, nie rozwiążą konfliktu między indywidualizmem i egzystencją człowieka opartą na prawie naturalnym, wbudowaną w porządek ładu społeczno-ekonomicznego. Nie jest więc słuszne przyjmować, iż „demokracje rozwiązały czy nawet wystarczająco zbadały problem konfliktu między indywidualizmem i ładem społecznym. Gdyby natomiast argument demokratyczny brał pod uwagę jakąś nową i zmodyfikowaną wersję umowy społecznej, nie jest wykluczone, że dałoby się znaleźć zadowalające rozwiązanie" [Stankiewicz 2003, s. 22]. Konieczny jest zatem rodzaj umowy społecznej konstytucyjnie gwarantowanej, na której zasadzałby się system społeczno-gospodarczy eksponujący wartości zadowalające wszystkich członków społeczeństwa. Taki system wymaga opracowania całościowej teorii demokracji bazującej na spójności jednostkowej i społecznej, a nie ich wykluczaniu. Demokratyczne rozwiązywanie konfliktu wartości bez idei umowy społecznej - jest złudzeniem opartym na nieporozumieniu.

\section{Zakończenie}

Współczesne uwikłanie form demokracji w ekonomiczny determinizm, oparty na wolnościowej idei neoliberalnej, nie czyni zadość istocie wolności człowieka, żyjącego w społeczności wspólnotowej - społeczeństwie pojmowanym jako całość, a nie zbiorowości jednostek. Jak wykazano w punkcie pierwszym opracowania, jest to typ demokracji urynkowionej wprowadzającej zaburzenia świadomościowe wyborców, wykreowane przez pożądane cele określonych grup interesów. To w gruncie 
rzeczy zaprzeczenie idei istotowej demokracji, mającej gwarantować wolność, równość członkom społeczeństwa nie tylko w sensie prawnym, jak ma to miejsce obecnie, ale wolność w określaniu samej wizji egzystencji społeczeństwa. Nie wystarczy udoskonalanie form demokracji płynące $\mathrm{z}$ inspiracji postrzegalnych form empirycznych. Potrzebny jest namysł teoretyczny związany z refleksją, czym jest wolność człowieka realizowana w obszarze jednostkowym i obszarze wspólnoty społecznej i czym jest idea rozwoju człowieka odwołująca się do prawa naturalnego. Teoretyczna synteza inspirowana tymi trzema kwestiami prowadzi, w odniesieniu do budowy relacji społeczno-ekonomicznych, do pożądanego modelu SO i adekwatnego do niego systemu demokratycznego. Rozważania o uwarunkowaniach SO pomieszczono w drugiej części opracowania. Końcowa część to prezentacja kierunków udoskonalenia demokracji. I nie chodzi tu o szersze doskonalenie form demokracji bezpośredniej jako uzupełnienie demokracji przedstawicielskiej. Chodzi o wyłonienie makroekonomicznego poziomu demokracji bezpośredniej umożliwiającej wnoszenie celów społecznych i egzystencjalnych, decydujących o kształcie ładu społeczno-ekonomicznego, na podstawie którego można wprowadzać ustrojowe rozwiązania. Niewątpliwie potrzebna jest do tego forma SO jako forma jego upodmiotowienia. Do jego zaistnienia konieczne jest kształtowanie świadomości obywatelskiej, za którą są odpowiedzialne elity danego społeczeństwa.

\section{Literatura}

Bauman Z., 2008, Zindywidualizowane społeczeństwo, Gdańsk.

Broda-Wysocki P., 2003, Rozwój społeczeństwa obywatelskiego w Polsce, Warszawa.

Filipowicz S., 2007, Demokracja. O władzy iluzji w królestwie rozumu, Warszawa.

Guzik A., 2012, Sondaże opinii publicznej jako samowiedza współczesnych społeczeństw, [w:] Elementy świadomości politycznej wspótczesnego społeczeństwa polskiego, red. K. Łabędź, Kraków.

Kelsen H., 1936, O istocie i wartości demokracji, Księgarnia Powszechna, Warszawa.

Kowalczyk S., 1999, Filozofia wolności, Lublin.

Kowalczyk S., 2005, Człowiek a społeczność. Zarys filozofii społecznej, Lublin.

Legutko R., 2010, Czy demokracja jest ustrojem madrym?, [w:] Demokracja dla wszystkich, red. J. Pluta, E. Stawowa, S. Wilkanowicz, Kraków.

Linder W., 2011, Blaski i cienie demokracji bezpośredniej, [w:] Demokracja bezpośrednia, Semper, Warszawa.

Nowa encyklopedia powszechna PWN, t. 2, Warszawa 1995.

Olbromski O.J., 2011, Demokracja w okowach totarientalności, Warszawa.

Patel R., 2010, Wartość niczego. Jak przeksztatcić spoleczeństwo rynkowe i na nowo zdefiniować demokracje, Warszawa.

Pieniążek A., 1988, Społeczeństwo i jednostka, Lublin.

Saward M., 2010, Demokracja, thum. A. Burek, Warszawa.

Stankiewicz W.J., 2003, Niezbędność teorii politycznej, tłum. B. Czaykowski, Wrocław.

Stankiewicz W.J., 2010, Demokracja w teorii i praktyce, Wrocław.

Szymonik M., 2010, W kierunku demokracji personalistycznej, Warszawa.

Szyszkowska M., 2012, W opozycji do przeciętności czyli własna droga do wolności, Białystok. 
Śliwa M., 2010, Demokracja polska, Warszawa.

Tilly Ch., 2008, Demokracja, tłum. M. Szczubiałka, Warszawa.

Tocqueville A., 1976, O demokracji w Ameryce, thum. M. Król, Warszawa.

Vatter A., 2011, Demokracja bezpośrednia w Szwajcarii: historia, debaty i skutki, [w:] Demokracja bezpośrednia, Warszawa.

Wilkanowicz S., 1993, Jak wybierać dobrych postów, radnych, senatorów?, [w:] Demokracja dla wszystkich, red. E. Pluta, E. Stawowy, S. Wilkanowicz, Kraków.

Ziżek S., 2014, Żąanie niemożliwego, tłum. B. Baran, Warszawa. 